\title{
Patriotic Education in the Process of Youth Socialization in Conditions of Hybrid Warfare
}

\author{
Sergii Savchenko* \\ Rector, Taras Shevchenko Luhansk National University, Luhansk, Ukraine, Correspondence Member of the National Academy of Pedagogical \\ Sciences of Ukraine \\ Vitalii Kurylo \\ President, Taras Shevchenko Luhansk National University, Luhansk, Ukraine, Academician of the National Academy of Pedagogical Sciences of \\ Ukraine
}

\begin{abstract}
The article deals with the analysis of the problem of patriotic education in the process of youth socialization in conditions of hybrid warfare. Based on their own personal many-years' experience as educators and top-officials of the higher educational establishment which had been displaced from the military zone in the east of Ukraine and implementing a number of sociological methods of research, the authors state that patriotism can essentially influence the formation of an individual's political culture in general identifying his attitude to the history, traditions and religious preferences of his nation, to the evaluation of the nation's place and role in the modern world. The authors arrive at the conclusion that patriotism determines political orientations of an individual towards the political institutions of a society, towards a political system as well as towards an individual's personal participation in the political life. A special emphasis is made on the idea that in modern Ukraine which actually faces Russia's hybrid warfare in Donbas, patriotism serves as the most important value which does not only integrate a social potential of an individual but also his spiritual, moral and cultural potentials.
\end{abstract}

Keywords: Patriotic education; Youth socialization; Hybrid warfare; Political culture; Mechanisms of socialization.

(C) (1) CC BY: Creative Commons Attribution License 4.0

\section{Introduction}

The problem of youth socialization has strongly occupied its niche in the scientific investigations aimed at studying the influence of the society on the formation of an individual. There has been collected a significant theoretical and empirical material that explains the mechanisms of socialization and its institutions, defines its main agents and stages, serves a foundation for the discussions on its kinds, etc. including the problem of patriotic education in the process of students' socialization. See works by Archard (1999), Arneson (2005), Brooks (2015), Callan (2006), Hulas and Fel (2015), Kateb (2007), Kierkegaard (2013), Kleinig et al. (2015), Königs (2012), Moore (2009), Nussbaum (2012), Primoratz (2002), Soutphommasane (2012), Zdenko (2011), Zembylas (2014), etc.

At the same time it is too optimistic to say that everything is definite and clear in these processes and that the theory of socialization is close to its scientific completion. This is connected with the fact that social processes themselves are so numerous and diverse that their influence on different social groups (regardless their age-specific peculiarities) becomes rather controversial and can hardly be well-predicted. It is even more obvious when it goes about patriotic education in the process of youth socialization in conditions of social and political instability such as, for example, a hybrid warfare.

\section{Materials and Methods}

The problem of patriotic education has a complex character which predetermines the implementation of various subject-matter spheres of research, the revelation of which appears indispensably necessary for the construction of an integral pattern of the analyzed phenomenon as well as the necessity to turn to different theoretical and methodological bases. The main methodological basis of our research lies in the reflection of the problem of formations of patriotism at students' youth at a complex level in conditions of a hybrid warfare. This requires taking into account a number of factors among which are the following ones: the specificity of students' youth as a social group, the character of institutional processes in the modern society including their mutual interaction. This idea has been well describe in the book by R. Curren and Ch. Dorn "Patriotic Education in a Global Age" (Curren and Dorn, 2018).

The implementation of general sociological methods makes it possible to create the primary pattern of the analyzed object and to receive qualitative and quantitative data regarding the main aspect of the Ukrainian students who happened to find themselves in the situation of hybrid warfare in the east of Ukraine. The results of the surveys and their profound analysis allows us getting a substantial empirical basis for the verification of theoretical hypotheses worked out in the process of the research. 
Special attention is paid to the analysis of youth's social world outlook which has at least two important research tasks: to determine the structure of the world outlook and to consider the inner mechanisms of the formation of outlook guidelines.

The use of the paradigm theory makes it possible to analyze the outlook structures aimed at defining their integrity and inner consistency, establishing the main regulations of their origin, development and distribution, making a complex research of the processes realized at the level of social and cultural reality.

Within the framework of our research, we rested upon the historical approach which ensured the analysis of the dynamic processes of the social structures that is valuable for a deeper understanding of modern political situations and for forecasting of further possible changes of these social structures.

\section{Results and Discussion}

One of the main characteristics of modern socialization is that its mechanisms thoroughly analyzed by social pedagogics which are typical for a certain social situation can easily be totally transformed with the change of social conditions. For instance, the processes of socialization of individuals in the peacetime can change drastically in conditions of transition to social disturbances such as those that we are observing now in Donbas during the hybrid warfare. It is most distinctly revealed in such a personality quality as patriotism.

It is worth mentioning, first of all, that the transition from peace to war, even if it goes about an undeclared war and it has a hybrid character, is always accompanied by the changes in the established balance of personality qualities and value orientations. Those of them which used to dominate before switch to the background whereas others, such as patriotism, for instance, start to prevail. Of all the characteristics of patriotism, we are, first and foremost, interested in those which reflect its social nature. It goes without saying that the main social and psychological feature of patriotism is that it can be formed only in a society, in the process of socialization, i.e. with the help of its mechanisms.

The leading one among them is surely connected with the goal-directed education realized in different preschool, school, university and army groups. However, the social space for the development of patriotism is not at all limited by them. A significant role in this aspect is played by the family and other social institutions such as mass media, public organizations, cultural and sports institutions, religious organizations, law-enforcement agencies, social protection offices, corporate associations, etc. (Bekh, 2018; Petrochko and Okushko, 2017; Petrochko, 2018).

The role of patriotism in the process of socialization of youth is greatly preconditioned by its universality as a social phenomenon, by the multivaluedness of its manifestation, by the integrated interdependence with other personality formations significant for individuals.

In order to understand the influence of patriotism on the results of individuals' socialization, it is important to analyze its potential and psychological mechanisms by means of which significant changes take place in the development of a person.

First of all, we would like to emphasize that patriotism can essentially influence the formation of an individual's political culture in general identifying his attitude to the history, traditions and religious preferences of his nation, to the evaluation of the nation's place and role in the modern world.

Patriotic guidelines formed in the process of socialization define an individual's orientation in the dichotomy between "friendly and alien" thus ensuring his political identification. What is important in this connection is that these mechanisms can also function in case of the formation of links at the level of macro-societies - attitudes towards large social groups, ethnoses, peoples, other countries, etc.

Patriotism makes a decisive influence on the political stereotypes which are being formed in the world outlook of young people. At the same time it can hardly be a guarantee of a certain objectivity. On the contrary, some simplified and sketchy ideas about history, its separate facts, political events in different countries can easily be formed in the youths' awareness, strained for the needs of a certain political situation. An example of this can be found in the distortion of truth about the Kievan Rus, the Ukrainian history in general, its historical figures to please the Russian propaganda which is served up with the dressings of Russian patriotism, the uniqueness of Orthodox faith, the adherence to the heroic deeds of the great ancestors, etc.

On the other hand, the neglect of patriotic values, the absence of an efficient patriotic education can lead to high social risks and problems. A person who does not feel love to his Motherland, who has no respect to its history, who does not experience a feeling of commitment to his compatriots as a united social community can behave indifferently and even hostilely towards his own country in any critical situation. This is what happened in Donbas in 2014 when the majority of the population reacted mainly indifferently to the Russian aggression and invasion while a significant part of it explicitly took the aggressor's side turning into traitors and collaborators.

Among a number of reasons that led to such a situation one of the main roles was played by the lack of a system-defined work on patriotic education in Donbas that had been the case for the whole period of the history of independence of Ukraine. Such an underestimation of patriotism as an important component of social awareness has naturally led to the weakening of the social and economic, spiritual and cultural links with the central Ukraine, to the negative perception of the Ukrainian society and state, which could not but affect the quality of socialization of a coming generation.

This had been preceded by the post-Soviet years of radical social and market transformations during which a great many of standards of social life were ruined which led to the rise of indifference, cynicism, selfishness, lack of responsibility, a disrespectful attitude towards the state and social institutions in the youths' awareness.

The study of patriotism and its influence on socialization require a consideration of such an important aspect as the formation of youths' world outlook. Upbringing of young patriots and the revival of the Ukrainian patriotic idea 
are the main tasks of the state which can hardly be solved without the fullness of knowledge on the place which patriotism occupies in the system of value orientations, its role in the formation of the world outlook of young Ukrainians. The events that unleashed in the east of Ukraine showed that there took place the discrepancy between the actions aimed at acquiring patriotism by the residents of Donbas and the spontaneous formation of values in the youths' environment which are understood differently than they are defined in the official curricula of patriotic education.

This discrepancy reflects a contradiction of the tasks of patriotic education which lies in the discord between the declared aims and the actual social life especially in the front-line area of Donbas. The continuous attempts to forcibly transmit patriotic values via the Ukrainian mass media dash against an aggressive propaganda of the Russian mass media which, unfortunately, often appears more efficient and comprehensive.

A significant peculiarity of patriotism as a personal quality lies in the variety of forms of its manifestation in different social groups that include pupils, young workers and professional class, the unemployed, students. Following the specificity of our research, we are interested in the latter. Based on a vast empirical material, we managed to define the peculiarities of manifestation of patriotism in the students' environment which had not been so clearly expressed before.

It goes about the interconnection between the level of the material security of students and their patriotic attitudes. In modern Ukraine (as well as in many other countries, by the way), a significant worsening of the material state of students forces young people to combine their academic studies and professional activities. On the one hand, this has a negative effect on their academic achievements, on the other hand, due to the acquired professional experience, this transforms the process of the formation of value orientations diluting the socializing influence of a higher educational establishment.

Thus, a professional pedagogical influence on the formation of patriotism is substituted by spontaneous impacts which are predetermined by an individual's professional activity, his social environment and relations in the group. Unfortunately, the economic situation formed in modern Ukraine is too far from being positive or at least satisfactory which determines the influence of such a situation that will last during a long period of time that can hardly be calculated.

This situation cannot but influence the process of the formation of value orientations contributing to the reinforcement of negative attitudes and protest moods, to the decrease of a general level of patriotism.

As a result, the real understanding of patriotism by students and its manifestation as a value orientation does not always coincide with regulatory patterns fixed in curricula and programs of patriotic education and upbringing.

In the end of 2015, the President of Ukraine issued the decree "On the Strategy of National and Patriotic Education of Children and Youth for the Period of 2016-2020". Among the aims of the Strategy, the following were declared, namely:

- the formation of the national and cultural identity, national and patriotic world outlook, the preservation and development of spiritual and moral values of the Ukrainian people;

- the awareness of the achievements of the Ukrainian people, their intellectual and spiritual heritage;

- the development of people's commitment in the formation of the Ukrainian state, the formation of an active civil position among the children and youths and the sense of their personal dignity;

- a coordination and cooperation between the bodies of state power and local authorities in the sphere of national and patriotic education, their efficient interaction with the public;

- the formation of a wide civil support of the processes of national and patriotic education, the extension of the role and possibilities of civil organizations, the increase of the role of family, an active participation of volunteers and activists;

- the guarantee of system-defined changes, the achievement of a high quality, efficiency and predicted development in the sphere of national and patriotic education;

- the contribution to the consolidation of the Ukrainian society around the ideas of common future, the defense of the territorial integrity of Ukraine, the reforms in the sphere of state formation and development (Legislation of Ukraine, 2015).

However, students being a leading referent group for the majority of the youth may transmit values different from those fixed in the regulatory documents influencing in this way other representatives of the youth: schoolchildren, young workers and employees, young countryfolk, etc. This is dangerous and, to a great extent, can contribute to the marginalization of the young generation of Ukraine, to the increase of the level of anxiety in the youths' environment, their dissatisfaction of life, to the aggressiveness and social indifference. It is quite natural that such conditions do not at all ensure the growth of patriotic moods in the east of Ukraine and give birth to waves of emigration to the countries the European Union from the west of Ukraine.

The above said allows us stating that patriotism is a complex social and cultural phenomenon which is characterized by a diversity of its content and a variety of forms of its manifestation in different social situations. Still, there exists a sphere of social life in which the socializing potential of patriotism is revealed most strongly. This is the sphere of politics or political socialization which we understand as a process of an individual's acquisition of political knowledge, standards and values that let him adequately function as a mature member of a society.

At the same time patriotism represents the most important element of an intentional influence on an individual, his education and upbringing. By no means it should turn into a spontaneous process influencing his development and formation. Political socialization combined with the historical experience of a certain country and people predetermines the patterns of an individual's political behavior as well as the political behavior of different social groups and social institutions. 
One of the informal functions of patriotism is the correction of the main functions of political culture. It sets certain standards both in the content of patriotism and in the practical mechanisms of its realization. As a result, an individual can a) focus on political processes evaluating them according to his own ideological positions; b) successfully adapt to an unfamiliar political environment; c) work out initial habits of his political behavior; d) understand his political identification and social commitment; e) communicate with different subjects of politics on the basis of common political interests.

At the same time patriotism can also function as a destructive personal quality imposing aggressive political ideologies on individuals and social groups which serve a foundation of a political culture. Besides, the phenomenon of patriotism can lead to the domination in a society of political ideologies of a wide range: from extremely rightist ones to radically leftist ones.

One of the most ancient and actively used functions of patriotism that influences the results of an individual's socialization is its myth-forming function. Since the ancient times political history of the mankind has created a great number of myths about the religion, science, public figures, etc. With the help of mythologization lasting stereotypes are created which are based on faith and let politicians interpret the fact and events of the past, present and future in the way they need it.

Another powerful instrument of patriotism along with mythologization is a political symbolism. Such symbols as flags, coats of arms, hymns, political slogans, appeals, memorial dates, political rituals, etc. have an influence on the attitude of individuals, social groups and the society in general towards the organization of their life activity.

\section{Conclusions}

Summing up the results of the analysis of the problem of interaction of patriotism and political culture, it is worth defining the directions of impact of the former as a personal quality on the process of the formation of the latter.

Patriotism determines political orientations of an individual towards the political institutions of a society, towards a political system as well as towards an individual's personal participation in the political life.

Patriotism makes a significant influence on the formation of an individual's political experience helping him to make a conscious ideological choice. At the same time patriotism eagerly imposes political ideologies of quite a different range on individuals, social groups and a society in general.

Patriotism makes a crucial influence on the existing political stereotypes in a society defining their characteristic features.

Patriotism is the main element of a purposeful influence on an individual which in the combination with the historical experience of older generations predetermines patterns of behavior of individuals, social groups and social institutions.

Thus, patriotism possesses a huge potential in the process of socialization of children and young people. The task is that it should be most efficiently realized at the level of youth and educational policy, in the policy in the sphere of childhood.

In modern Ukraine which actually faces Russia's hybrid warfare in Donbas, patriotism serves as the most important value which does not only integrate a social potential of an individual but also his spiritual, moral and cultural potentials.

\section{References}

Archard, D. (1999). Should we teach patriotism? Studies in Philosophy and Education, 18(3): 157-73.

Arneson, R. J. (2005). Do patriotic ties limit global justice duties? Journal of Ethics, 9(1-2): 127-50.

Bekh, I. (2018). Patriotism as a value: essence and future prospects. Education: Modern Discourses, 1: 185-91.

Brooks, D. (2015). The road to character. Random House: New York.

Callan, E. (2006). Love, idolatry, and patriotism. Social Theory and Practice, 32(4): 525-46.

Curren, R. R. and Dorn, C. (2018). Patriotic education in a global age. University of Chicago Press: Chicago, IL, USA. 192.

Hulas, M. and Fel, S. (2015). Intricacies of patriotism: Towards a complexity of patriotic allegiance. Peter Lang: Frankfurt am Main.

Kateb, G. (2007). Are patriotism and universalism compatible? Social Theory and Practice, 32(4): 609-24.

Kierkegaard, S. (2013). Fear and trembling. Princeton University Press: New Jersey.

Kleinig, J., Keller, S. and Primoratz, I. (2015). The ethics of patriotism: A debate. Wiley Blackwell: Oxford.

Königs, P. (2012). Patriotism: A case study in the philosophy of emotions. Grazer Philosophische Studien, 85(1): 299-309.

Legislation of Ukraine (2015). Strategy of national-patriotic education of children and youth for 2016-2020 years. Available: http://zakon.rada.gov.ua/laws/show/580/2015

Moore, M. (2009). Is patriotism an associative duty? Journal of Ethics, 13(4): 383-99.

Nussbaum, M. (2012). Teaching patriotism: Love and critical freedom. University of Chicago Law Review, 79(1): 215-51.

Petrochko (2018). National and patriotic education of children and youth: questions of standards and indicators. Education: Modern Discourses, 1(2018): 200-06. 
Petrochko and Okushko, T. K., 2017. "National-patriotic education in ukraine in the context of current challenges." In Naukove zabezpechennia rozvytku osvity v Ukraini: aktualni problemy teorii i praktyky (do 25-richchia NAPN Ukrainy). Zbirnyk naukovykh prats. Kyiv: Vydavnychyi Dim Sam, 45-51. (in Ukrainian).

Primoratz, I. (2002). Patriotism: A deflationary view. Philosophical Forum, 33(4): 443-58.

Soutphommasane, T. (2012). The virtuous citizen: patriotism in a multicultural society. Cambridge University Press: Cambridge.

Zdenko, K. (2011). Is education for patriotism morally required, permitted or unacceptable? Studies in Philosophy and Education, 30(2): 127-40.

Zembylas, M. (2014). The teaching of patriotism and human rights: An uneasy entanglement and the contribution of critical pedagogy. Educational Philosophy and Theory, 46(10): 1-17. 